\title{
Kinerja Kelompok Tani Dalam Sistem Usahatani Padi Lahan Rawa Dan Metode Pemberdayaannya: Studi Kasus Pada Kegiatan Padi Sawah Di Lahan Sub Optimal Kabupaten Tanjung Jabung Barat Jambi
}

\author{
Firdaus, dan Suharyon \\ Balai Pengkajian Teknologi Pertanian (BPTP) Jambi
}

\begin{abstract}
ABSTRAK
Terdapat 17 kelembagaan dalam usahatani padi dimana kelompok tani mempunyai peran yang cukup penting dalam hampir setiap tahapan usaha tani. Namun mayoritas kelompok masih dalam tingkatan pemula dengan kinerja yang rendah. Indikator kinerja kelompok tani berdasarkan SK Mentan No. 41/Kpts/OT.210/1992 mendekati sempurna sehingga implementasinya menuntut usaha yang serius. Dari hasil pengamatan di lapangan diketahui bahwa faktor-faktor yang menentukan kinerja kelompok tani adalah jumlah anggota, struktur dan aset kelompok, status anggota kelompok dalam pemilikan lahan, kredibilitas pengurus, dan kelembagaan penunjang. Tiga metode pemberdayaan kelompok yang dapat diterapkan meliputi : 1) sosialisasi program yang diawali dengan perkenalan antara fasilitator dan petani dan dilajutkan dengan penjelasan enam isu penting tentang program yaitu : apa, siapa, kapan, dimana, bagaimana; 2) menerapkan pendekatan partisipatif dan bottom up; 3) mengikutsertakan ibu tani yang berperan sebagai motivator dalam adopsi serta sosialisasi teknologi.
\end{abstract}

Kata kinci : Kelompok Tani, kinerja, padi, Lahan rawa, usaha tani, motivasi

\section{PENDAHULUAN}

Permasalahan sosial dalam pengembangan pertanian akhir-akhir ini disadari sebagai faktor yang menentukan keberhasilan adopsi teknologi ditingkat petani. Di antara berbagai permasalahan sosial yang ada, kelembagaan merupakan salah satu faktor yang harus dicermati unhtuk mengetahui kelembagaan yang perlu mendapatkan perioritas berkaitan dengan upaya meningkatkan usahatani khususnya padi di lahan sub optimal.

Menurut Yudianto (2000), kelembagaan adalah pola perilaku manusia yang sudah mapan. Lumis (2001) memberikan nengertian yang lebih luas bahwa kelembagaan mengandung dua pengertian yaitu : 1) hubungan timbal balik atau interaksi yang berulangulang dan membentuk reaksi yang rsisten, dan 2) suatu kejadian yang mempengaruhi secara nyata tindakan atau cara berpikir suatu individu masyarakat. Pengertian kelembagaan secara operasional mudah dimengerti dan dijumpai di lapang adalah yang diukemukakan oleh Warisno (2002) bahwa kelembagaan dikelompokan ke dalam dua pengertian yaitu institute dan institusi. Institut menunjuk pada kelembagaan formal, misalnya organisasi, badan, dan yayasan mulai dari tingkat keluarga, rukun keluarga, desa sampai pusat, sedangkan institusi merupakan kumpulan-kumpulan norma-norma atau nilai-nilai yang mengatur perilaku manusia untuk memenuhi kebutuhannya. Dari pengertian kelembagaan tersebut maka yang dimaksud dengan kelembagaan dalam system usahatani (SUT) adalah kelembagaan formal dan institusi/normanorma yang berkaitan dengan semua tahapan kegiatan SUT mulai dari persiapan lahan sampai pemasaran hasil.

Berdasarkan hasil penelitian Alihamsah et al (2001), Ananto et al (2001) terdapat 17 kelembagaan yang ada ditingkat desa yang berkaitan dengan SUT padi. Tujuh belas kelembagaan tersebut adalah : 
1. Kelokmpok tani

2. Kelompok wanita tani

3. Perkumpulan petani pemakai air (P3A)

4. Kontak tani Nelayan Andalan (KTNA)

5. Gabungan kelompok tani (Gapoktan)

6. Penyuluh pertanian lapangan (PPL)

7. Koperasi tani (Koptan)

8. Koperasi unit desa (KUD)

9. Kelompok arisan

10 Kelompok simpan pinjam

11 Kios saprodi

12 Pedagang pengumpul/tengkulak

13 Pasar

14 Jasa angkutan

15 Jasa alsintan

16 Kilang padi

17 Lembaga swadaya masyarakat (LSM)

Peran kelembagaan tersebut disajikan pada Tabel 1.

Tabel 1 menunjukkan bahwa ada tiga kelembagaan utama yang diperlukan hampir di setiap kegiatan usahatani padi, yaitu kelompok tani sebagai pemegang peran penting diikuti oleh PPL dan jasa alsintan. Pentingnya kelompok tani tersebut didukung oleh banyaknya jumlah kelompok tani di Indonesia yang mencapai 254.898 kelompok (Pusat Penyuluhan Pertanian, 2002). Jumlah kelembagaan lainnya adalah Koptan 8.498 buah, LSM 525, yayasan 142, dan KTNA 152 buah. Karena banyak dan pentingnya peran kelompok tani maka kinerjanya perlu ditelaah lebih lanjut.

Untuk menelaah kinerja kelompok tani dalam memajukan usahatani padi dilakukan analisis kelembagaan. Menurut Taryoto (1995), analisis kelembagaan dalam bidang pertanian adalah analisis yang ditujukan untuk memperoleh deskripsi mengenai suatu fenomena sosial ekonomi pertanian yang berkaitan dengan hubungan antara dua atau lebih pelaku interaksi sosial ekonomi, yang mencakup dinamika aturan-aturan yang berlaku dan disepakati bersama oleh para pelaku interaksi, dinamika perilaku yang ditunjukkan oleh pelaku interaksi disertai dengan analisis mengenai hasil akhir yang diperoleh dari hasil interaksi. 
Dari defenisi tersebut dapat disimpulkan bahwa dalam analisis kelembagaan, penekanannya terletak pada proses interaksi antara dua individu atau lebih yang mencakup tiga kategori yaitu, 1) atura-aturan/kesepakatan, 2) kinerja dinamika, dan 3) hasil akhir. Ketiga kategori tersebut digunakan untuk menganalisis eksistensi kelompok tani. Setelah mengetahui kinerja kelompok selanjutnya dikemukan berbagai temuan program pemberdayaan dalam usaha meningkatkan kinerja kelompok tani.

Tulisan ini menguraikan kelembagaan yang mengelompokkannya mengacu pada Warisno (2000) dikaitkan dengan kegiatan dalam SUT khususnya SUT padi dilahan sub optimal dan dibatasi pada kelembagaan formal, yaitu kelompok tani.

Tabel 1. Peranan kelembagaan formal dalam kegiatan usahatani padi di lahan sub optimal

\begin{tabular}{|c|c|c|c|c|}
\hline $\begin{array}{ll}\text { Jenis kegiatan } & \text { dalam } \\
\text { usahatani padi } & \end{array}$ & PPL & $\begin{array}{l}\text { Kelompok } \\
\text { tani }\end{array}$ & $\begin{array}{l}\text { Jasa } \\
\text { alsintan }\end{array}$ & Lainnya \\
\hline Penentuan jenis komoditas & $\mathrm{x}$ & $\mathrm{x}$ & & BPTP,Pemda \\
\hline $\begin{array}{l}\text { Penentuan teknologi } \quad \text { yang } \\
\text { diterapkan }\end{array}$ & $\mathrm{x}$ & $\mathrm{x}$ & & ВРТP \\
\hline Pengadaan benih & & $\mathrm{x}$ & & Balitpa,KUD,Koptan \\
\hline Pengadaan pupuk & & $\mathrm{x}$ & & Kios,KUD,PT Pertani \\
\hline Pengadaan pestisida & & $\mathrm{x}$ & & Kios,KUD \\
\hline Pengadaan alsintan & & $\mathrm{x}$ & & Koptan \\
\hline Waktu pengolahan tanah & $\mathrm{x}$ & $\mathrm{x}$ & & BPTP \\
\hline Pelaksanaan pengolahan tanah & & $\mathrm{x}$ & $\mathrm{x}$ & \\
\hline Pengairan & $\mathrm{x}$ & & & $\mathrm{P} 3 \mathrm{~A}$ \\
\hline Waktu persemaian & $\mathrm{x}$ & $\mathrm{x}$ & & \\
\hline Waktu tanam & $\mathrm{x}$ & $\mathrm{x}$ & & BPTP \\
\hline Pengendalian gulma & & $\mathrm{x}$ & & \\
\hline Penyiangan & & $\mathrm{x}$ & $\mathrm{x}$ & \\
\hline Panen & & $\mathrm{x}$ & & \\
\hline Perontokan & & $\mathrm{x}$ & $\mathrm{x}$ & \\
\hline Pengeringan & & & $\mathrm{x}$ & \\
\hline Penyimpanan & & & $\mathrm{x}$ & \\
\hline Pengolahan hasil & & & $\mathrm{x}$ & \\
\hline Jumlah & 6 & 13 & 6 & \\
\hline
\end{tabular}

Sumber: Alamsyah et al (2001), Ananto et al (2001), Pranaji et al (2001).

\section{Kelompok Tani}

Kelompok tani dibentuk berdasarkan surat keputusan dan dimaksudkan sebagai wadah komunikasi antar petani, serta antar petani dengan kelembagaan terkait dalam proses alih teknologi.Surat keputusan tersebut dilengkapi dengan ketentuan-ketentuan atau tolak ukur untuk memonitor dan mengevaluasi kinerjanya. Kinerja tersebut akan menentukan tingkat kemampuan kelompok. 


\section{METODOLOGI PENGKAJIAN}

\section{Indikator Kinerja Kelompok Tani}

Penilaian kinerja kelompok tani didasarkan pada SK Mentan No. 41/Kpts/OT.210/1992 yang indikatornya seperti tertera pada Tabel 2.

Tabel 2. Tolak ukur penentuan tingkat kemampuan kelompok tani (didasarkan lima jurus kemampuan kelompok

\begin{tabular}{|l|l|}
\hline Jurus kemampuan & Nilai \\
\hline $\begin{array}{l}\text { Kemampuan merencanakan kegiatan untuk meningkatkan produktivitas } \\
\text { usahatani padi (termasuk pasca panen dan analisis usahatani) dengan } \\
\text { menerapkan rekomendasi yang tepat dan memanfaatkan sumber daya alam } \\
\text { secara optimal) }\end{array}$ & 300 \\
\hline Kemampuan melaksanakan dan menaati perjanian dengan pihak lain & 100 \\
\hline Kemampuan memupuk modal dan memanfaatkannya secara rasional & 100 \\
\hline $\begin{array}{l}\text { Kemampuan meningkatkan hubungan yang melembaga antara kelompok } \\
\text { dengan KUD }\end{array}$ & 200 \\
\hline $\begin{array}{l}\text { Kemampuan menerapkan teknologi dan memanfaatkan informasi serta } \\
\text { kerjasama kelompok yang dicerminkan oleh tingkat produktivitas dari } \\
\text { usahatani anggota kelompok }\end{array}$ & 300 \\
\hline J u m l a h & 1.000 \\
\hline
\end{tabular}

Sumber: Bakorluh Provinsi Jambi (2015).

Kegiatan penilaian melibatkan kelembagaan terkait dengan prosedur sebagai berikut : 1) penelaahan laporan kegiatan lapang, 2) penilaian oleh tim yang terdiri dari PPL, petugas tingkat desa, kecamatan dan kabupaten, 3) penyerahan hasil penilaian kepada camat, selanjutnya kepada dinas pertanian kabupaten/kota, 4) pengecekan oleh dinas pertanian tingkat provinasi. Berdasarkan nilai yang dimiliki oleh kelompok tani selanjutnya ditentukan jenjang yang layak disandang oleh kelompok tani yang bersangkutan (Tabel 3).

Indikator diatas merupakan hasil penyempurnaan indikator sebelumnya (8 indikator) yang diciptakan oleh Slamet (1999) yaitu : 1) tujuan kelompok, 2) struktur kelompok, 3) fungsi tugas, 4) tekanan pada kelompok, 5) pembinaan kelompok, 6) kekompakan, 7) suasana kelompok, 8) efektivitas kelompok. Indikator tersebut diantaranya diaplikasikan oleh Suyatna (1990) untuk melihat kedinamisan kelompok sosial tradisional, menyimpulkan bahwa tekanan pada kelompok merupakan faktor penting bagi keberhasilan kelompok. Utomo et al juga mengemukakan indikator tersebut untuk mengevaluasi kelompok. 
Tabel 3. Kalasifikasi kelompok tani berdasarkan kemampuannya

\begin{tabular}{cc}
\hline Klasifikasi & Jumlah nilai \\
\hline Pemula & 250 \\
Lanjut & $251-500$ \\
Madya & $501-750$ \\
Utama & $751-1.000$ \\
\hline
\end{tabular}

Sumber : BP4K Kabupaten Tanjung Jabung Timur, 2014

Faktor penentu dalam dinamika kelompok juga memperkaya informasi dan melengkapi faktorfaktor yang perlu diperhatikan dalam meningkatkan kinerja kelompok.

\section{Kinerja Kelompok Tani}

Berbagai penelitian mengenai kelompok tani telah dilakukan dengan tolak ukur yang berbeda-beda. Perbedaan tolak ukur ini mungkin disebabkan peneliti belum mengetahui perbedaan tolak ukur yang ada, atau telah mengetahui tetapi tidak mungkin menerapkannya karena berbagai keterbatasan. Antara lain penelitian mempunyai kepentingan tertentu terhadap suatu aspek yang hendak diteliti.

Zakiah et al (2000) telah mengamati dinamika kelompok tani berdasarkan SK Mentan No. 41/Kpts/OT.210/1992 diwilayah Proyek Pengembangan Lahan Rawa Terpadu (Integrated Swamps Development Project = ISDP). Proyek ini implementasinya dimulai tahun 1994/1995 sampai di Riau, Jambi, Palembang, dan Kalimantan Barat. Disimpulkan oleh Zakiyah et al (2000) bahwa menurunnya dinamika kelompok disebabkan oleh faktor teknis dan faktor sosial. Faktor teknis diantaranya adalah kegagalan panen oleh berbagai sebab seperti serangan hama dan kondisi air, sedangakan faktor sosial yang utama adalah realisasi dari perencanaan yang sudah disepakati yang selalu tidak bisa ditepati. Faktor sosial lainnya adalah kurangnya kepercayaan anggota terhadap pengurus dalam mengelola modal kelompok, keberadaan petugas yang dapat membina kelompok, dan rendahnya kemampuan untuk menjalin hubungan dengan lembaga lain khususnya dengan koperasi desa. Ditegaskan bahwa hubungan kelompok dengan koperasi dan penyandang dana lainnya sangat menentukan dinamika kelompok. Kelompok yang semula sudah mencapai jenjang utama, setelah KUD nya tidak aktif lagi, dinamikanya agak menurun, sedangkan kelompok KUD nya aktif dinamikanya makin tinggi.

\section{HASIL DAN PEMBAHASAN}

\section{Hasil Akhir Eksistensi Kelompok Tani}

Dari hasil-hasil temuan yang telah dikemukakan diperoleh gambaran bahwa kinerja mayoritas kelompok tani masih rendah dan memerlukan bimbingan. Hal ini disebabkan mayoritas kelompok tani masih pada tingkatan fomula (Tabel 3).

Berbagai usaha untuk meningkatkan kinerja kelompok telah dilakukan dengan hasil yang bervariasi. Dari pengalaman kegagalan dan keberhasilan tersebut dapat dipetik suatu pendekatan atau metode pemberdayaan yang mampu mendorong peningkatan kinerja kelompok tani. 


\section{Pemberdayaan Kelompok Tani}

Pemberdayaan berarti memberikan motivasi dan dorongan kepada masyarakat individu untuk menggali potensi yang dimiliki untuk kemudian ditingkatkan kualitasnya agar mampu mandiri . Salah satu metode pemberdayaan untuk memaksimalkan kinerja kelompok tani yang telah dilakukan adalah corporate farming (CF) yaitu suatu program yaqng menawarkan kerjasama dalam pengelolaan usahatani agar memberikan hasil maksimal.

Pengkajian CF secara khusus diawali dengan sosialisasi program tentang mamfaat dan keuntungan mengelola usaha tani secara bersama-sama diikuti dengan kesepakatan oleh petani untuk melaksanakan kegiatan yang akan dilakukan secara berkelompok dan kegiatan yang masih dilakukan secara individu setelah sosialisasi terdapat enam kegiatan yaitu : 1) penentuan teknologi yang diperlukan, 2) jenis komoditas yang diusahakan, 3) paket teknologi yang dibutuhkan, 4) pengadaan saprodi, 5) pengadaan alsintan, dan 6) pengairan. Kegiatan secara individu yang masih dilakukan : 1) penyemaian, 2) penyiangan, 3) pengeringan, 4) penyimpanan, 5) pengolahan hasil. Dilokasi pengkajian petani sepakat melakukan enam kegiatan secara bersama. Memperhatikan lebih banyak kegiatan yang dilakukan secara bersam dapat disimpulkan bahwa tujuan CF untuk mengelola usahatani secara bersama pada perinsipnya sudah bisa diterima oleh petani. Kegiatan tersebut berhasil karena diawali dengan sosialisasi program terlebih dahulu. Pemberdayaan Kelembagaan di Desa Karya Bakti, Kecamatan Rantau Rasau Kabupaten Tan jung Jabung Timur Jambi.

Pemberdayaan kelompok tani Karya Baru Desa Karya Bakti, Kecamatan Rantau Rasau cukup baik dalam merespon kehadiran peneliti, petugas lapang, dan Instansi terkait sehingga terjadi interaksi yang baik antara kedua belah pihak, terutama dalam mencari solusi yang terbaik untuk memecahkan kendala yang ada di lapangan. Kesempatan itu perlu disyukuri karena sudah kelihatan hasil dan bantuan baik secara teknologi maupun bantuan saprodi lainnya.

Kendala lain dalam introduksi teknologi di lokasi kegiatan bervariasinya kondisi lahan sehingga produksi dan komoditas yang ditanam juga bervariasi. Untuk itu diberikan penjelasan khusus kepada petani tentang teknologi yang dihasilkan oleh BPTP dan dipadukan dengan hasil penenlitian dari Instansi lain. Teknologi lahan sub optimal atau lahan pasang surut yang diperkenalkan kepada mereka merupakan hasil uji coba sebelumnya oleh BPTP yang bekerjasama dengan Balittra untuk diterapkan di lokasi Desa Karya Bakti.

Program pemberdayaan dikelompok tani Karya Baru yang sedang berjalan adalah memberikan motivasi bahwa kekompakan dan kegotong royongan, kebersamaan, dan saling mengisi sangat berguna bagi peningkatan kesejahteraan keluarga. Dengan memberikan informasi dan pengarahan dalam pertemuan kelompok ternyata sudah mampu melahirkan kelompok tani Karya Baru. Contoh-contoh lainya yang diberikan adalah berkembangnya jasa simpan pinjam yang dimulai dari berbagai kegiatan yang dilakukan secara berkelompok seperti iuran kelompok dengan tujuan adalah mendapatkan hasil usaha dikemudian hari.

Kerjasama kelompok diwujudkan dalam kegiatan pemberantasan hama tikus dengan mempergunakan alat perangkap, dan penanaman. Kegiatan tersebut semula dikerjakan dengan mengupah secara individu, namun kemudian dilakukan secara berkelompok. Biaya yang seharusnya dibayarkan jika mengupah dimasukkan kekas kelompok yang selanjutnya disimpan pinjamkan untuk keperluan usahatani (pembelian saprotan) maupun keperluan lainnya. 


\section{KESIMPULAN DAN IMPLIKASI KEBIJAKAN}

Kelompok tani mempunyai peranan penting dalam pengembangan usahatani, namun 40 persen kelompok tani masih berada pada tingkatan pemula. Faktor yang mempengaruhi kinerja kelompok di antaranya adalah jumlah anggota, struktur dan aset kelompok, status anggota kelompok dalam pemilikan lahan, kridibilitas pengurus, dan kelembagaan penunjang.

Untuk meningkatkan kinerja kelompok tani perlu dilakukan pemberdayaan yang diawali dengan perkenalan antara petugas/peneliti dan petani, serta sosialisasi program yang menjawab enam pertanyaan itu, yaitu : apa, siapa, mengapa, dimana, kapan, dan bagaimana. Keberhasilan pemberdayaan dapat dicapai jika dilakukan mulai dari bawah. Bersifat partisipatif, serta mengikut sertakan semua anggota kelompok.

Untuk meningkatkan usahatani padi maka kinerja kelompok tani perlu ditingkatkan dengan memperhatikan hal-hal berikut : jumlah anggota maksimal 30, struktur kelompok dilengkapi dengan seksi pemasaran dan permodalan, memperhatikan status anggota kelompok dalam pemilikan lahan memilih ketua kelompok yang solid, serta menjalin kerjasama aktif dengan lembaga penunjang.

Keputusan petani menjalankan usahatani di lahan rawa tidak saja dipengaruhi faktor eksternal seperti keberadaan pasar input/output dan dukungan kelembagaan serta kebijakan pemerintah. Akan tetapi kondisi biofisik lahan usahatani yang kurang kondusif juga besar sumbangannya dalam mempengaruhi keputusan petani.

Untuk mendukung terlaksananya strategi tersebut diperlukan adanya sentuhan permodalan berupa skim kredit usahatani dengan bunga lunak tanpa agunan dan pendampingan penerapan teknologi yang intensif oleh penyuluh dan peneliti

\section{DAFTAR PUSTAKA}

Anonim, 2018. Programa Penyuluhan Pertanian Wilayah Kerja UPTD Jambi Selatan, 2019. Dinas Pertanian dan Ketahanan Pangan, Kota Jambi.

Alihamsah.T,E.E. Ananto,H. Supriadi,S.Wahyuni,E.Suhartatik, Astanto,F. Tangkuman,K.Nugroho, dan N.Sutrisna. 2000. Karakteristik Wilayah Pengembangan ISDP Provinsi Jambi. Pusat Penelitian dan Pengembangan Tanaman Pangan, Bogor.

Ananto,E.E,. Asnanto, Sutrisno, dan R. Tahir. 2000. Prospek pengembanganalat mesin pertanian.

Badan Pelaksana Penyuluh Pertanian, Perikanan, dan Kehutanan (BP4K) Kabupaten Tanjung Jabung Timur, (2014). Data kelompok tani, Gapoktan, dan klasifikasi kemampuan kelompok tani Se Kabupaten Tanjung Jabung Timur.

Badan Kordinasi Penyuluh Pertanian Provinsi Jambi, 2012. Petunjuk Pelaksanan Penilaian Kelompok Tani.

Dinas Pertanian Tanaman Pangan Provinsi Jambi, 2017. Laporan Tahunan. Dinas Pertanian Provinsi Jambi. 
Hartati,S. dan S.Wahyuni, 2001. Laporan pengkajian kinerja dan arah pengembangan BPP di Sumatrra Utara. Badan urusan Ketahanan Pangan. Pusat Penelitian dan Pengembangan Sosial Ekonomi Pertanian Bogor.

Ratna.D. dan S.Wahyuni, 2001. Pemberdayaan kelompok wanita tani dalam defuse dan adopsi teknologi SUT Lebak. Pusat Penelitian dan Pengembangan Tanaman Pangan Bogor.

Slamet.M, 1999. Dinamika Kelompok. Fakultas Pertanian Bogor.

Suyatna,IG. 1990. Ciri-ciri Kedinamisan Kelompok Sosial Tradisional di Bali dan Pengaruhjya dalam Pembangunan. Disertasi Sekolah Pascasarjana Institut Pertanian Bogor.

Taryoto,A.H. 1995. Analisis kelembagaan dalam penelitian social ekonomi pertanian. Proseding Pengembangan hasil Penelitian. Pusat Penelitian dan Pengembangan Sosial Ekonomi Pertanian Bogor.

Warisno,R.M. 2002. Penelitian Pemberdayaan kerja sama kelembagaan Integrated Swamp Development Project. Badan Litbang Pertanian, Jakarta.

Yudianto, 2000. Kamus umum Bahasa Indonesia.M25. Bandung.

Zakiah,E.E. Aananto, dan D.E. Sianturi, 2000. Laporan tahunan 2000. Proyek Penelitian Pengembangan Pertanian Rawa Terpadu. Badan Litbang Pertanian, Jakarta. 